\title{
The Mastery of the English Language In Reducing Cultural and Communication Barriers In Tourism World.
}

\author{
Dr. Acep Unang Rahayu, M.Ed. TESOL \\ SekolahTinggiPariwisata Bandung, Indonesia \\ acepurz@yahoo.com
}

\begin{abstract}
This study aims at giving some thoughts that cultural differences influence a great deal in English communication. This research is limited to a brief theoretical background of the importance of mastering the English language and how cultural and communication barriers can be reduced. The data of this research were taken from English novels and their translations in Indonesian, and from students in real situation at hospitality institution, Bandung Tourism Higher Education. In this research some thoughts of English and Indonesian linguists are compared. In Indonesia Misunderstandings frequently take place in any situations especially in understanding written English, for examples: The problems for Indonesian students lie on understanding the meaning of English Progressive in the first place, and interpreting Indonesian Progressive sentences into English. Other English constructions such as Simple Present, Simple Past, Present or Past Perfect Simple have no problem in translating into Indonesian. Cultural differences also make barriers in communication. That is why it is important to solve the problem to avoid misunderstanding. The author's contributions to this problem are as follows: explaining the importance of mastering English, teaching culture differences between English and Indonesian, and investigating English progressive correspondences in Indonesian to limit misunderstanding
\end{abstract}

Key words:-Mastering, cultural differences, misunderstanding, communication barriers.

\section{I.INTRODUCTIONS}

In Indonesia English is as International language used as a compulsory language taught from elementary to university degree, and English is the foreign language which should be mastered because most of the literature from many angles of knowledge is written in English. Other foreign languages such as French, Mandarin, Japanese and Arabic are learnt as optional foreign languages. This problem makes most of Indonesian students face difficulties in understanding spoken and written foreign languages especially English as the first International language to master in Indonesia. Other influencing problem is that the Indonesian structure is totally different from English or other foreign languages mentioned above. For example, in English, Subject is usually followed by a verb, while in Indonesian language, Subject can be followed by a noun or adjective.

The Indonesian youth's oath spoken in 1928 is a bench mark for Indonesian unity strengthened by the statement that the
Indonesian language is the tool for unity and identity of Indonesian country. Though there are many tribes living in Indonesia from the West to the East of Indonesia, besides halfmixed ones (Indo-Europe, Indo-America, Indo-Australia etc.) Indonesian language is the national language for communication. The usage of Indonesian language must be maintained and developed. On the other hand, foreign language terms such as English are inevitable to understand due to the development of knowledge, and international companies establishment which is developing widely and running successfully. Media plays important role in contributing new terms for Indonesian language. Therefore, understanding foreign languages in Indonesia is a must. However, culture influences a great deal in transmitting ideas, norms, traditions, behavior, languages, beliefs, etc.whereby everybody shares in a particular social group. In Indonesia there are thousands of vernacular and of course cultural diversity makes it difficult to communicate. Different cultures, different mindset and different expressions make it difficult for Indonesian people to understand foreign language such as English. Thus, all these factors perform as a barrier to effective communication in tourism world in Indonesia. Therefore, the study of the English language mastery in reducing cultural and communication barriers, is needed.

\section{II.LITERATURE REVIEWS}

Let us start some views about the foreign language and culture :"[1]Manuela, G.(2002:166) points out that " Learning a foreign language/culture implies widening one's horizons in terms of concepts, norms and values, in other words, to discover otherness and develop a relationship with it in wider terms than one does gradually in one's native society". I agree to a certain extend that learning a foreign language or culture implies widening one's horizons, however understanding the culture that the foreign language brings should be learnt step by step to strengthen understanding the foreign language that someone is learning, especially in tourism world. Other opinion supporting this,"[2] J.Richardson \& M.Fluker (2004:75) argue that "Culture is very important to tourism. One of the most compelling motivations for people to travel is to see now other people live and to learn something of their cultural heritage". In line with this, "[3]Langacker, R.(1999:16) supports the argument that "Language is an 
essential instrument and component of culture whose reflection in linguistic structure is pervasive and quite significant". From those views we learn that language reflects culture, and culture may shape some one's ways of thinking. Let me take "[4]Sneha,M's (2006:7) opinions who describes some causes of cultural barriers as follows: Firstly, Language; It is said that people who do not understand nor communicate properly in English can cause various misunderstandings that leads to a communication barriers. Secondly, Behavior and beliefs; behavior and beliefs are shaped by cultural differences, for examples: body language, thinking, communication, manners, norms that leads to miscommunication. It is given example that in some cultures eye contact is considered as polite manner whereas in some it is rude and disrespectful. Beliefs; are also other influencing factor to people's perception as given in the example that those who believe in God can handle problems with their lives compared to those of Atheists who are more hardworking. Thirdly, Ethnocentrism; it is a thought that other's culture or tradition is not better than some one's perception of his or her culture or tradition. This may lead to hostility and barrier in communication. Lastly, Religion; It is believed that ethnocentrism and stereotyping is rather similar to religion that may disrupt communication. Religion views influence other's way of thinking, as a result different opinions are made up. Let me give an example that in Indonesia, Moslem people are majority compared to Hindu, Christian and others. Communication amongst believers seem rigid, due to different way of religion thinking. It is further discussed that there are other cultural barriers such as political opinions, gender, life etc. It is arguable that cross cultural communication may not be the only barrier, on the other way it can be a trigger for creating new perspective and openness". Therefore, cross cultural understanding should be increased to limit communication barriers. Coming back to the background of the English Language, let me quote a brief history of the English language from a direct source by "[5]M. Boyanova (2015) who describes that the English language belongs to the West Germanic branch of the Indo-European family of Scots and Frisian. Whereby Frisian is a language spoken by the Dutch province of Friesland, nearby areas of Germany, and on a few islands in the North Sea. The history of the English language has traditionally been divided into three main periods: Old English (450-1100 AD), Middle English (1100circa $1500 \mathrm{AD}$ ) and Modern English (since 1500). Over the centuries, the English language has been influenced by a number of other languages. It is said that during the 5th Century AD three Germanic tribes (Saxons, Angles, and Jutes) came to the British Isles from various parts of northwest Germany as well as Denmark. These tribes were warlike and pushed out most of the original, Celtic-speaking inhabitants from England into Scotland, Wales, and Cornwall. One group migrated to the Brittany Coast of France where their descendants still speak the Celtic Language of Breton today". From the description above, we learn that it is important to understand the relationship between language and culture. In Indonesian situation where the writer works, some cultural and communication barriers have found. The institution where I work trains students to work in hospitality industries. The English language as one of foreign languages must be mastered for communication at workplace. As described previously that having different culture and language, it is common to perform misunderstanding in communication especially in written or spoken English. Besides having Indonesian culture which is very much different from English, my students were born with their mother tongues. As a note here that there 33 provinces in Indonesia with thousands of islands and local vernaculars. As mentioned in the introduction part of this paper, English is a compulsory subject, hence English is taught in my Institution every day. In brief, one of the cultural and language barriers is the different structure between the English and Indonesian language. Here is one of the examples in terms of structure. For instance, the common tense term as English progressive structure used such as Present Progressive, Past Progressive and Perfect Progressive have their correspondences in Indonesian Language, but other English Progressive structure such as Future Present Progressive, Future Past Progressive, Future Present Perfect Progressive, and Future Past Perfect Progressive do not have their correspondences in Indonesian. Therefore, interpreting or translating Indonesian into English sometimes is confusing or misleading because of the difference in meaning and cultural background. As a result, misunderstanding takes place. The term English tense(s) is more common which explains the structure, usage, and time signals than aspectuality which explains more details in meaning. Let us take a look at some definitions of aspectuality put forward by some language experts as published in "[6] Acep.U.R.'s (2015) journal", one of the experts as " [7] J.Lyons (1995:37) explains that "aspectuality derives from Russian word "Vid" which refers to perfective and imperfective differences". Other opinion by"[8]C.Murcia (1999:20) describing that "aspectuality is related to an internal structure of action which happens anytime". He divided aspectuality to simple, perfect, progressive and the combination of perfect progressive". Supporting the others "[9] Binnick (2003:10) mentions two kinds of aspectuality "imperfect aspectuality and continuous aspectuality". Agreeing with the previous researchers,"[10]Acep U.R. (2007:52) describes that "aspectuality as a grammatical category which reflects the way an action of verb viewed from time space. He further mentions that in English there are two kinds of aspectuality, those are Perfect and Imperfect (progressive) which are combined in verb frase and marked by at present or past". ,'[11] Acep U.R. (2015) states that In fact, aspectuality is closely related to tenses. While aspectuality explains the inherent meaning, tenses describe when the situations take place".

\section{DISCUSSION}

In this section I will firstly discuss briefly the importance of mastering the English language, and secondly, how cultural 
differences cause communication barrier, finally, how cultural and communication can be reduced.

Returning to the examples of English structure mentioned in the literature reviews above that my students at Bandung Higher Institution (Sekolah Tinggi Pariwisata Bandung) face problems, here I will illustrate some of the examples data taken from English novels where situational conversations were chosen and selected as examples of English Aspectuality Progressive. Then the Indonesian translation of each situational conversations of Aspectuality Progressive were compared to find their correspondences, and some data from my investigation during class hours where my students were doing their English presentations. The research aimed to find kinds of English Progressive Aspectuality and kinds of Indonesian grammatical meanings found in the constructions of English Progressive Aspectuality". Here are few examples (also see [12]"Acep,U.R.(2015) ) of English Progressive Aspectuality and their correspondences in Indonesian language taken from English novels No Greater Love (1991:15-306) and The Ranch (1997:95-203) by D. steel[13][14] and their translations Yang Terkasih (2002:29-436) by I.K Hidayat [15] and Masih Ada Hari Esok (1999:84-158) by Ramayanti [16]. The Sky Is Falling ((2001:29-229) by S. Sheldon[17] and Its Translation Langit Runtuh (2005:38-234) by S. Hidayat [18]. In my observation, in terms of Present and Past Progressive aspectuality, both data taken from the novels and my students, do not show any significant problems in both interpreting and translating. Therefore, those data will not be discussed here further. However, the problems found in Present Perfect Progressive, Past Perfect Progressive, Present Future progressive, Past Future Progressive, and modals with Present Perfect Progressive. Here are the data:

1. Present Perfect Progressive

The data were taken from The Ranch and its translation Masih Ada hari Esok.

a." I've been letting him punish me"

b. "Inilah cara dia menghukumku"

This shows one of examples of a mismatch translation due to difference culture between English and Indonesian language. The Perfect Progressive tells unfinished past situations continuing to the present moment, while in Indonesian language we do not have this kind of Progressive situation. The English Perfect is generally translated "sudah or telah", while English Progressive is translated "sedang or lagi". However, in the context of Present Perfect Progressive above, the use of "sudah sedang", "sudah" that indicates Perfect, and "sedang" that indicates Progressive in the Indonesian translation, is omitted. So, both Present Perfect Simple and Present Perfect Progressive are mostly translated into Indonesian using "sudah". Because there is no proper expression in Indonesian language for Perfect Progressive. Hence, misinterpretation or misundrstanding may occur. The above translation may be more proper translated as "Saya sudah membiarkan dia menghukumku".

2.Past Perfect Progressive

The data were taken from No Greater Love and its translation Yang terkasih. a. "George hadn't been kidding when he said it".

b. "George tidak main-main mengatakannya".

A different correspondence takes place in the above sentence. A common translation for this kind of Progressive should be the same as what has been explained in point 1 above. Where Perfect Simple, both Present or Past is translated "sudah or telah" in Indonesian language, but the translation is found surprising that the use of "tidak main-main" which means not kidding as in the translation for Past Simple Progressive such as in "He was not kidding when He said it". The writer expected the above English sentence would be translated as at least using "sudah". In contrast to this situation, if the Past Perfect Progressive sentence above as in "George hadn't been kidding when he said it", and its Indonesian translation "George tidak main-main mengatakannya', using the word "sudah for perfect and "sedang" for Progressive for this translation will not be common in Indonesian language such As in "George sudah tidak sedang main-main mengatakannya". From this, I hope that we will learn that language and culture differences between English and Indonesian could be minimized. The invention of lexical expression in Indonesian for English Perfect Progressive should be made.

3.Present Future Progressive

The data were taken from The Sky Is Falling and its translation Langit Runtuh.

a." I don't think I'll be coming back to Washington, Dana"

b" aku rasa aku tidak akan kembali ke Washington Dana".

The other finding of my research as in this example in which the Indonesian word "sedang" is supposed to use normally for denoting progressiveness. In the translation above the word "sedang" is not used. The above translation is the same as the one used for expressing Simple Present Future such as in "I'll come back" and its translation is "aku akan kembali". The word Will is translated into "akan" in Indonesian. The negative sentence "I don't think" is "Saya rasa tidak", but in this example, the negative word is translated in the Future sentence way as if it were "I won't be coming back". The flexibility in translating for this sentence takes place. However, the use of "sedang" after the word "akan" which refers to Future meaning in the translation will not sound strange. For example: "saya akan sedang kembali ke Washington" for "I'll be coming back to Washington ". What we learn from this is that the inherent meaning of English Aspectuality Progressive should be understood to have better understanding.

4.Past Future Progressive

The data were taken from No Greater Love and its translation Yang Terkasih.

a. "They would be sailing on her maiden voyage".

b."Mereka akan menumpang kapal baru dalam pelayaran perdana ya".

In this example, the same case as in point 4 whereas the word "sedang" is not used. Therefore, it will be difficult to differ between Future Past Progressive " They would be sailing" and Future Past Simple "They would sail". The use of "sedang" in the translation will be acceptable as in" mereka akan sedang 
menumpang" which means both English Progressive and its translation refer to a situation in progress. As a note, in this example the translator freely expresses her way of translating it by putting the word "kapal baru" which means a new ship that is actually not written in the English sentence above. In this example the translator may relate the new ship to the sailing. So, we learn from here that translating or interpreting may mean explaining thing inherently.

5. Modals with Progressive

The data were taken from The Sky Is Falling and Langit Runtuh.

a. "The woman may be dying".

b. "Wanita itu mungkin akan meninggal".

In this example, the English sentence which refers to a situation in progress is translated in the same way as the Indonesian sentence is constructed. So, there is no problem in translating or expressing both English and Indonesia.

6.Modals with Present Perfect

The data were taken from The Ranch and its translation Masih Ada Hari esok.

a. "She must have been doing it for months".

b."Dia pasti telah melakukannya selama

berbulan-bulan".

Different from the English sentence, in Indonesian sentence the word "sedang" which refers to a situation in progress is omitted. This may mean the same as we translate it into "She must have done it for months". So, what we learn from this example is that, English modals are translated properly in Indonesian, while the English Progressive sentence remains the same as it is an English Simple sentence.

To my surprise, the data taken from my classroom research were almost the same as those of found in the novels. Most of my students rarely used Perfect Progressive form in their spoken nor written. When they translated Perfect Progressive, they never used Indonesian lexical Progressiveness "sedang' in between Indonesian lexical "sudah" which denotes Perfectness. As in this example" I have been studying here for 2 years" "saya sudah belajar di sini selama 2 tahun". In contrast to this, the Indonesian translation above will be translated by the students who lack knowledge of English structure as in "I have studied here for 2 years". Which is totally different in meaning from "I have been studying here for 2 years". It is clear that the explanation of the different meaning between Perfect Progressive and Perfect Simple must be described clearly to the Indonesian students. However, the experienced students having no difficulties understanding both of them. It is simple anyway to explain the different between Perfect Simple and Perfect Progressive, simply by using the Indonesian lexical word "sudah" which means finish for Perfect Simple, and Indonesian lexical "masih" which means still. So, the proper and common Indonesian correspondence for Perfect Progressive sentence "I have been studying here for 2 years" is "Saya masih belajar di sini sudah 2 tahun lamanya" instead of " saya sudah belajar di sini selama 2 tahun" which refers to "I have studied here for 2 years". From this only simple example on the real situation, we learn that how different and complex each language is, both English and Indonesian. Therefore, the mastery of English knowledge is compulsory to reduce cultural and communication barriers. This is what is happening in Indonesia, one of the reasons the number of tourists coming to Indonesia is lower than its neighboring countries such as Singapore, Malaysia and Thailand, is because of communication barrier. Indonesia is not less attractive nor beautiful than its neighboring countries, there are many places of interest to visit. However, as supported by [19]" Van der Schaar (2016) that besides infrastructure, education also forms an obstacle. Although on the island of Bali as well as in the luxury hotels of Jakarta most native people working in the tourism sector are pretty fluent in English (and sometimes even other non-Indonesian languages), in the more remote areas of Indonesia natives have difficulty to communicate with tourists. Therefore, a focus on the study of English would help to overcome this situation. This language barrier has been reason for a portion of Singaporeans to choose Malaysia as their holiday destination instead of Indonesia. Most foreign visitors that enter Indonesia come from Singapore, followed by Malaysia and Australia ".The discussion on the language mastery above is clear that, to master the English language needs some knowledge which is gained by educational process. That is one of the reasons in Bandung Tourism Higher Education (sekolah Tinggi Pariwisata Bandung), Indonesia, English is a compulsory subject taught every day to reduce communication barrier.

Returning to the discussion on cultural, as described on the literature reviews above that there are some factors underlying cultural barriers. Since, the tourism world offers many chances for business development, however as given an example above of the remote areas of Indonesia natives having difficulties to communicate with foreign tourists, this ineffective crosscultural communication is obviously harmful for customers and stakeholders as well as for themselves as employees. Hence, it is important to be aware of the cross-cultural communication barriers and learn how to overcome them. Learning the English language is one of the overcoming solutions, for there are many things we can learn not only the English structure or grammar, but also interesting cultural lesson inclusions which tell us various kinds of cultural differences from body gestures, manners, phrases, symbols, ways of thinking, norms, and social things, etc.

To close the discussion, I would argue that Understanding foreign language such as English with its cultural package is not easy, it takes times to master. However, the needs of tourism world business development should motivate those working and studying in hospitality industries and tourism world.

\section{CONCLUSION}

In conclusion, I have talked about the English language and cultural differences in comparison to Indonesian which trigger some of many things in making communication barriers to take place in tourism world. To end this paper I will recommend, firstly, that it is important to master the English language for those studying, working and developing business in hospitality industries and tourism world. Secondly, 
Teaching and learning other cultures, besides foreign languages should be enhanced to reduce cultural and communication barriers.

\section{References}

[1] Manuela, G..Critical Citizens for an intercultural world.Foreign language Education as cultural politics, Cromwell Press ltd, U.K.Pp. 166, 2002.

[2] John,Ricardson \&Martin fluker. Understanding and Managing Tourism.Pearson Hospitality Press. Printed In Malaysia.Pp. 75 . 2004

[3] Langacker, R..Grammar and Conceptualization. Berlin: Walter de Gruyter.Pp. 16, 1999.

[4] Sneha.M. How to overcome cultural and Communication barriers.In Http://www. How to overcome cultural and Communication barriers in workplace.Pp.7 2006

[5] M Boyanova. A brief history of The English language in http://www. A brief History of the English language. 2015

[6] Acep.U.R. 2015. Differences on language structure between English and Indonesian in International journal of languages, literature and linguistics. Vol.1 number 4.

[7] J.Lyons. 1995. J. Lyons," Pengantar Ilmu Linguistik". P.T. Gramedia Pustaka Utama, Jakarta, Indonesia. Pp.37, 1995.

[8] C. Murcia,"Grammar book;an ESL.EFL Teacher's Course", second edition.USA.: Heinle and Heinle Publishers.pp.20, 1999.

[9] J.Binnick, "Tense, Verbal Aspect, Aktionsart and Related areas .Available URL.:http//www.Invisible light house.com/langtab aspect.html., Pp10, 2003.
[10] Acep U.R. "The English Progressive Aspectuality And Its Correspondence In Indonesian (Structure and Semantic Analyses).A Doctoral Dissertation, Padjadjaran University Bandung. Indonesia. "Unpublished",pp.52,2007.

[11] Acep.U.R. Differences on language structure between English and Indonesian in International journal of languages, literature and linguistics. Vol.1 number 4.Dec. 2015

[12] Acep.U.R. 2015. Differences on language structure between English and Indonesian in International journal of languages, literature and linguistics. Vol.1 number 4.Dec.2015.

[13] D. Steel, "No Greater Love,"New York: Dell Publishing Inc. Steel, Daniel.1991. No Greater Love.New York: Dell Publishing Inc.pp.15306.

[14] D. Steel, "No Greater Love,"New York: Dell Publishing Inc. Steel, Daniel.1991. No Greater Love.New York: Dell Publishing Inc.pp.15306.

[15] I.K. Hidayat,"Yang Terkasih",PT.Gramedia Pusaka Utama, Jakarta, Indonesia. pp.29-436, 2002.

[16] Ramayanti,"Masih Ada Hari Esok", C.V.Karyono, Yogyakarta, Indonesia,pp. 84-158, 1999.

[17] S. Sheldon, "The Sky Is Falling",Harper Collins Publishers. Inc. U.S.A.,pp.29-229,2001.

[18] Hidayat,"Langit Runtuh",P.T.Gramedia Pustaka Utama, Jakarta, Indonesia.pp. 38-234, 2005.

[19] Van der Schaar.Tourism Industry Indonesia in http://www.Indonesia Investment. April 2016. 